\title{
OTORITAS, KEBERLANJUTAN DAN PERUBAHAN FIKIH DALAM PANDANGAN WAEL B. HALLAQ
}

\author{
Oleh: Muhammad Rofiq \\ Fakultas Ilmu Sosial dan Politik \\ Universitas Muhammadiyah Yogyakarta \\ E-mail: muhammadrofiq@umy.ac.id
}

\begin{abstract}
The existence of fiqh becomes one of the intellectual and integrated treasures in thedaily practices of Moslem. Thus, it has been internalized in the understanding of both the authors and the readers. The existence of fiqh that has been rooted since the beginning of Islam to the recent days has encouraged many scholars to study, research, and conduct several explorations. One of the scientists who are concerned about studying Islamic law is Wael, an orientalist whom views are considered to be sympathetic to Islam. In the study of fiqh, Wael presents new findings related to the authority and sustainability of Islamic law in the framework of madhhabs that he has studied. He concluded that the stagnation of Islamic law has never occurred. Indeed, it continues its progress from time to time. According to him, the statement that the door of ijtihad of having been closed is wrong. Thence, it becomes new thing in the intellectual world of Islam, which was once known as experiencing stagnation with the closing of ijtihad. Wael B. Hallaq examined specifically through intellectual work in three madhhabs of Islamic law, namely Thabaqat with historical analysis. He found a hierarchy of authority madhhab followers that he broke down from Thabaqat Maliki, Shafi'i and Hanafi.However, the established new characteristics which he discovered by shifting anti-taklid paradigm in Islamic law. The division of authorities that he described can be seen as a positive side of taklid. It becomes the point of the criticism, in which talkid should be the parameter of stagnation or sustainability of the law madhhabs in Islam. Therefore, the study conducted by Wael needs to be interconnected using other approaches to make it into amore comprehensive corrections.
\end{abstract}

Keywords: Fiqh, Wael B. Hallaq, Authority, Talkid

\section{A. LATAR BELAKANG}

Fikih adalah elemen integral yang menempati posisi penting dalam kehidupan umat Islam. Tidaklah berlebihan jika dikatakan bahwa dinamika internal yang terjadi dalam disiplin ilmu ini memiliki peran siginifikan dalam membentuk alur fluktuasi sejarah Islam. Lebih dari itu peradaban Islam sesungguhnya bisa diidentikkan dengan peradaban fikih itu sendiri, sama seperti peradaban Yunani yang identik dengan fil-safat (Abid Al-Jibiri, 1990: 97). Para sarjana (scholar) baik dari kalangan muslim mau-pun dari kalangan outsider (orientalis) tak kurang memberikan pengakuan terhadap pentingnya fikih atau hukum Islam dalam menentukan gerak langkah dan mengarah-kan pemikiran umat Islam. Joseph 
Schacht misalnya mengatakan bahwa fikih adalah ikhtisar pemikiran Islam, manifestasi paling tipikal dari pola hidup muslim serta me-rupakan inti dari saripati Islam itu sendiri (Syamsul Anwar, 2002: 147). Pada kajian sejarah Islam, Hamilton Gib (1979: 263) menyatakan bahwa fikih merupakan figur utama di antara sekian banyak disiplin ilmu lainnya yang ada dalam pemikiran Islam. Fikih adalah sentral afiliasi bagi seluruh ulama dari disiplin ilmu apapun. Abid Al-Jabi-ri (1990:97) seorang pemikir kontomporer dari Maroko juga menyatakan bahwa fikih lah satusatunya disiplin ilmu yang dianggap representatif untuk mengartikulasikan karakter peradaban Islam dengan segudang kekayaan khazanah intelektualnya.

Sejarah fikih sendiri dimulai dari masa yang sangat lampau, tepatnya ketika pertama kali al-Quran turun dan ketika pertama kali Muhammad Saw diangkat sebagai seorang rasul. Hal ini karena hukum yang lahir dalam ilmu fikih, terutama di masa awalnya tidak lain adalah produk dari metode derivasi (istikhraj, istinbath) dari ayat-ayat al-Quran dan Sunah nabi. Metode yang digunakan dalam ilmu fikih kemudian me-masuki perkembangan dan menjadi lebih terstruktur setelah imam Syafii $(204 \mathrm{H})$ dengan karya monumentalnya al-Risalah resmi mendeklarasikan lahirnya ilmu ushul fikih (Wael B. Hallaq. 1993: 587).

Munculnya problematika baru yang ditemui dalam kehidupan umat Islam di-tambah adanya berbagai kecendrungan dalam merumuskan hukum telah memuncul-kan ragam model dan pola dalam berijtihad, sehingga nanti pada masanya akan meng-giring sejarah fikih Islam berakumulasi pada terbentuknya berbagai macam mazhab (Wael B Hallaq, 2005).

Masa yang terbentang dari sejak zaman nabi sampai pertengahan abad keempat hijriyah disebut dengan periode pembentukan (formative periode, almarhalah al-ta'sisiyyah). Pada masa itu fikih Islam telah berada dalam titik mapan, di mana ber-bagai kecendrungan berijitihad muncul sehingga muncul pula bermacammacam mazhab. Pada periode awal Islam berdiri berbagai macam mazhab fikih, bukan hanya empat mazhab yang kita kenal saat ini. Tapi karena beberapa faktor yang multi-integral hanya empat mazhab saja yang tersisa dan bertahan. Memasuki abad ke lima hijriyah empat mazhab fikih yang ada memasuki fase kristalisasi yang ditandai deng-an lahirnya kitab-kitab thabaqât. Kitab-kitab tersebut menyusun struktur hirarki tokoh-tokoh mazhab berdasarkan kapasitas dan kemampuan mereka dalam menye-lesaikan kasus fikih partikular (juziyyat) dan kemampuan berinteraksi langsung dengan teks al-Quran dan Sunah.

Wael B. Hallaq adalah seorang sarjana yang memiliki concern dalam mengkaji hukum Islam (fikih) dan teori hukum Islam (Usul fikih). Tokoh ini memiliki beberapa pandangan yang relevan untuk dikaji berkenaan dengan penelitian dan penemuannya tentang kitab-kitab thabaqât. Berdasarkan penelisikan dengan pendekatan sejarah (historical approach) terhadap kitab-kitab thabaqât tersebut, Wael B. Hallaq menun-jukkan bahwa fikih Islam tidak pernah sama sekali stagnan. Karyanya yang berjudul Authority, Continuity and Change in Islamic Law, menjadi antitesis untuk teori sebe-lumnya bahwa klaim tertutupnya pintu ijtihad dan kejumudan fikih Islam adalah klaim yang sama sekali tidak benar. Pandangan Wael 
Diterbitkan oleh Fakultas Hukum

Universitas Ahmad Dahlan

B. Hallaq ini menarik dikaji kare-na temuan-temuannya sangat orisinil. Jika selama ini kitab-kitab thabaqât hanya di-anggap korpus yang merekam sejarah dan biografi tokoh-tokoh mazhab, Wael mam-pu mengubahnya dari sekedar 'dokumen mati' dan memanfaatkannya untuk meng-konstruksi sebuah fakta bahwa kitab-kitab tersebut merupakan rekaman yang me-nunjukkan adanya sisi progresifitas dan kreatifitas fikih Islam.

Tulisan ini mendeskripsikan temuan Wael B. Hallaq dalam artikelnya yang berjudul Juristic Typologies a Framework for Enquiry yang merupakan bab I dari buku-nya Authority, Continuity and Change in Islamic Law. Pada bagian akhir tulisan ini juga berusaha untuk mengkritisi pandangan Wael B. Hallaq yang sekiranya kurang relevan jika dilihat dari persepektif reformasi hukum yang diyakini oleh kelompok modernis.

\section{B. PEMBAHASAN}

\section{Biografi dan Sktesa Posisi Wael B. Hallaq di Tengah Orientalis Sebelumnya}

Mengenal tipologi kajian orientalisme di ranah hukum Islam sangatlah penting sebelum mengkaji Wael B. Hallaq, yaitu dalam rangka mengetahui aspek kontinuitas pemikiran Wael dengan pemikiran-pemikiran yang telah mapan pada periode sebelumnya. Selain itu, komparasi tersebut juga diperlukan untuk mengukur sejauh mana Wael mampu menyuguhkan contribution of knowledge dan berhasil keluar dari pengaruh-pengaruh para pendahulunya. Pada dasarnya tidaklah mudah membuat klasifikasi orientalis dan pemikiran mereka berdasarkan metodologi, motivasi atau kecenderungan hasil kajian mereka dalam ranah hukum Islam. Namun, tipologisasi itu diperlukan untuk mengetahui peta penelitian (framework for enquiry) para orien-talis.

Beberapa orientalis pada masa awal tidak dipungkiri jelas memulai kajian hu-kum Islam karena kepentingan ideologis, sehingga apa yang mereka hasilkan cen-derung reduksionis, tendensius dan tidak obyektif. Mustafa Abdul Raziq merekam te-muan orientalis yang hidup pada masanya tentang hukum Islam dalam karyanya al-Tamhîd fî Târîkh Falsafati'l Islâmiyyah. Sebagai contoh Abdur Raziq menulis tentang Carra de Vaux yang menyatakan dalam karyanya Les Penser de I'Islam bahwa fikih la-hir di masa pemerintahan Islam yang berpusat di Damaskus sehingga banyak bersing-gungan dengan undang-undang Byzantium (Romawi Timur). Abdur Raziq juga menu-lis tentang Ignadz Goldziher yang meyakini bahwa fikih adalah produk intelektual Is-lam yang lahir karena pengaruh (influence) dari agama Kristen dan Yahudi. Jika dita-rik benang merah dari penelitian dua orientalis ini ditemukan adanya kesamaan titik tolak (point of departure) kajian mereka yaitu pada isu autensitias dan orisinalitas fi-kih Islam. Berdasarkan argumen tentang genealogi (asal-usul) hukum Islam mereka meyakini bahwa produk intelektual di masa selanjutnya adalah khazanah yang lahir dari inferioritas peradaban Islam terhadap peradaban-peradaban sebelumnya. 
Setelah generasi di atas muncul pula beberapa orientalis yang concern mengkaji fikih Islam dari isu otoritas, di antara tokohnya adalah Coulson. Sarjana orientalis ini menuangkan pemikirannya dalam dua bukunya yang berjudul $A$ History of Islamic Law (Edinburg 1964) dan Conflict and Tensions in Islamic Jurisprudence (Chicago 1969) yang oleh Muhammad Muslihuddin (1991: xi) dinyatakan telah salah faham dalam membedakan pendapat para fukaha (fikih) dan syariah Islam itu sendiri.

Wael B. Hallaq, tokoh yang menjadi obyek kajian dalam makalah ini, adalah orientalis yang datang membawa gelombang baru dalam studi hukum Islam. Pendapat-pendapatnya dinilai sangat simpatik terhadap Islam. Ia misalnya secara eksplisit menyatakan bahwa beberapa karya intelektual yang ia susun adalah dalam rangka membentuk kutub baru dan sebagai anti tesis atas kekeliruan pandangan beberapa orientalis sebelumnya. Tentang temuan mengenai asal-usul sunah ia tak segansegan menyebut Goldziher, Schact, dan Juynboll terlalu skeptis dalam memulai kajian se-hingga berimplikasi pada lahirnya kesimpulan yang keliru tentang asalusul Sunah (Wael B. Hallaq, 2001: 3). Ia juga menyebutkan bahwa fakta historigrafi yang ada membuktikan al-Quran telah ada sejak zaman Nabi Muhammad Saw hidup. Ia mengutip pemikiran Mustafa A'zami (Wael B. Hallaq, 2001: 4) yang notabene adalah insider dalam kajian keislaman untuk membantah tesis orientalis sebelumnya.

Wael B. Hallaq adalah seorang professor di McGill University di Kanada. Ia me-rupakan seorang Kristen yang berdarah Arab dan lahir di Nazaret Palestina pada tahun 1955. Ia menyelesaikan jenjang doktoral pada University of Washington pada tahun 1985 (www.wikipedia.com, akses tanggal 25 Oktober 2009). Sejak tahun 1994 ia diangkat menjadi guru besar pada almamaternya dan pada tahun 2005 ia mendapat jabatan guru besar di McGill University. Ia adalah seorang pemikir dan penulis yang produktif dalam menghasilkan karya-karya di bidang Islamic Studies, terutama hukum Islam. Sampai tahun 2008, ia telah menyusun delapan buku tentang hu-kum Islam yang meliputi aspek sejarah, otoritas (doktrin), analisis terhadap pemi-kiran tokoh dan berbagai aspek lainnya. Selain itu ada lebih dari 35 artikel yang di-muat di beberapa jurnal dan ensiklopedi.

Melihat di antara karya-karya Wael yang banyak tersebut, ada tiga buku yang khusus ia susun sebagai kesatuan trilogi. Buku tersebut adalah $A$ History of Islamic Legal Theories: an Introduction to Sunnī Usūl al-fiqh; Authority, Continuity, and Change in Islamic Law, dan; The Origins and Evolution of Islamic Law. Buku pertama ia tulis un-tuk membantah tesa beberapa orientalis yang enggan mengakui adanya unsur al-Quran dan Sunah terhadap kemunculan dan lahirnya fikih Islam. Buku tersebut me-nyimpulkan bahwa fikih sangatlah responsif terhadap perkembangan masyarakat. Pada buku kedua ia mengelaborasi kitab-kitab thabaqât sebagai dokumen yang men-ceritakan hirarki otoritas fukaha pada masing-masing mazhab fikih. Sumbangsih pe-mikirannya pada buku itu adalah pernyataannya bahwa taklid adalah salah satu ben-tuk ijtihad kreatif yang dilakukan para fukaha pada era setelah abad 4 hijriyah. Me-lalui karyanya tersebut ia ingin mengatakan 
Diterbitkan oleh Fakultas Hukum

Universitas Ahmad Dahlan

bahwa teori pintu ijtihad telah dan per-nah tertutup yang telah lama bergaung tidaklah memiliki landasan analitis yang kuat. Pada buku ketiga ia mengulas tentang sejarah lahir dan evolusi fikih Islam. Tema sen-tral yang ia kemukakan di buku ini adalah tentang mazhab-mazhab fikih Islam dari aspek sejarah kemunculan, analisis terhadap keberhasilan empat mazhab masyhur dan menghilangnya mazhab-mazhab yang lain.

\section{Struktur Hirarkis Ulama Fikih (Thabaqât) dalam Tiga Mazhab}

Tipologisasi ulama adalah satu hal yang diperlukan, yaitu untuk mengetahui elemen pembentuk yang ada dalam tradisi setiap mazhab dan proses tranformasi otoritas dari satu tingkatan ke tingkatan lainnya (Wael B. Hallaq, 2001: 1). Tipologisasi ulama pada saat yang sama adalah representasi struktur mazhab-mazhab yang berkembang dalam sejarah hukum Islam. Untuk menelisik tipologi tersebut mau tidak mau kita harus membuka kitab thabaqât yang ditulis pertama kali pada pertengahan abad ke sepuluh. Wael B. Hallaq mengeksplorasi tiga dari empat mazhab yang populer di kalangan umat Islam. Sengaja ia tidak menganalisis thabaqât mazhab Hanbali kare-na Imam Ahmad bin Hanbal pendiri mazhab ini menurutnya lebih menonjol sisi hadisnya ketimbang sisi fikihnya.

Pada mazhab Maliki, tokoh yang pertama kali memuluskan jalan dalam penyusunan hirarki ulama adalah Ibnu Rusyd. Selanjutnya, tipologisasi Ibnu Rusyd me-lahirkan pengaruh besar terhadap framework fikih sesudahnya. Tipologisasinya di-tiru oleh ulama-ulama mazhab Maliki lainnya, semisal Wansyarishi dalam alMi'yar, Burzuli dalam al-Nawazil, Ibnu Salmun dalam al-'Iqdu'l Munazzam dan Hattab dalam Mawâhibu'l Jalîl. Ibnu Rusyd, dalam kitab Fatâwâ, membagi jenis orang yang bergelut dengan dunia fikih menjadi tiga golongan Pertama, golongan yang menerima ajaran mazhab Malik dengan tanpa disertai pengetahuan dari mana pendapat itu diambil atau disebut muqallid. Kapasitas yang dimiliki orang yang berada pada level ini hanya-lah menghafal aqwâl (pendapat-pendapat) Imam Malik dan sahabat-sahabatnya, tan-pa mengerti makna apa yang ia hafalkan dan tanpa adanya kemampuan membedakan mana di antara pendapat-pendapat tersebut yang benar dan mana yang salah.

Kedua, adalah golongan orang yang mampu menghafal seluruh pendapat dalam mazhab Imam Malik, memahami maknanya, mengerti dan mampu membedakan mana pendapat yang benar dan mana pendapat yang salah, akan tetapi mereka lemah dalam melalukan ijtihad langsung dari teks agama. Ketiga, golongan orang yang menghafal pendapat-pendapat dalam mazhab Malik, faham maknanya, mengerti dan bisa membedakan pendapat yang benar dan pendapat yang salah, dan sampai pada derajat mumpuni berijtihad secara langsung dari teks. Golongan ini memiliki penge-tahuan tentang seluk beluk ayat-ayat nâsikh-mansûkh, umumkhusus, muhkam-muta-syâbih dan hafal banyak hadist (Al-Wansyarishi, 1981: 32).

Sesuai dengan kapasitas mereka yang sangat minim, golongan pertama dinya-takan oleh Ibnu Rusyd tidak memiliki hak untuk mengeluarkan fatwa karena mereka hanya melakukan taklid. Sementara taklid sendiri bukanlah ilmu (lâ 'ilma 
'indahum). Ulama dalam strata ini tetap dibolehkan untuk mengamalkan ilmu yang mereka miliki dengan syarat tidak ada orang yang lebih kapasitasnya untuk dimintai fatwa. Pada kondisi demikian para muqallid (orang yang bertaklid) ini juga boleh untuk diikuti pendapatnya oleh orang lain dengan syarat mereka berfatwa dengan pendapat yang sudah ada dalam mazhab Malik. Akan tetapi ketika mereka berhadapan dengan kon-disi di mana dalam internal mazhab Malik terdapat banyak versi pendapat, dalam hal ini terjadi perbedaan pandangan dalam mazhab Malik, maka: (1) ia dibebaskan untuk memilih pendapat mana saja; (2) ia berijtihad (mencari kebenaran) dari sekian pen-dapat yang ada; (3) memilih pendapat yang paling berat. Adapun tingkatan kedua, mereka dibolehkan berfatwa dengan pengetahuan yang mereka miliki tentang maz-hab Malik setelah mereka terlebih dahulu yakin akan kebenaran fatwa mereka itu. Akan tetapi jika mereka menemukan permasalahan yang sama sekali tidak terdapat jawabannya dalam mazhab Malik ijtihad untuk golongan ini tidak dibolehkan. Golo-ngan ketiga diperbolehkan mengeluarkan fatwa dengan melalukan ijtihad dan analogi (qiyâs) dari al-Quran dan Sunah.

Sekitar kurang lebih satu abad kemudian seorang ulama penting dalam mazhab Syafii, Ibnu Shalah (643 H/1245), mengikuti jejak Ibnu Rusyd menyusun tipologi mujtahid dalam mazhab Syafii. Pada periode Ibnu Shalah atau pada abad ketujuh hij-riyah, mazhab Syafii telah memasuki periode kematangan, sehingga wajar apa yang disusun oleh Ibnu Shalah lebih rumit dan detail dari klasifikasi Ibnu Rusyd (Wael B. Hallaq, 2001: 7). Ibnu Shalah mengklasifikasikan jenis mufti ke dalam dua macam, yaitu mujtahid independen (mustaqil) dan mujtahid yang bergantung (ghairu mus-taqil) (Ibnu Shalah, 2002: 86). Mufti yang menduduki peringkat pertama atau sering disebut pula mujtahid mutlaq memiliki pengetahuan yang dalam tentang usul fikih, tafsir, hadist, nâsikh-mansûkh, Bahasa Arab yang mumpuni dan memiliki kemampuan untuk ber-instinbâth langsung dari al-Quran dan hadis. Kategori pertama ini oleh Ibnu Shalah diterapkan pada pendiri mazhab, yaitu Imam Syafii.

Kategori kedua yaitu mujtahid ghairu mustaqil adalah mujtahid yang mengikuti metode dan berafiliasi pada mazhab imam pendiri mazhab (Ibnu Shalah, 2002: 91). Mereka ini disebut juga mujtahid muntasib. Ada empat tingkatan mujtahid yang termasuk ke dalam kategori ini. Pertama, mujtahid yang memiliki kapasitas sama seperti yang dimiliki oleh imam pendiri mazhab. Mereka menjadi pengikut mazhab bukan karena taklid, baik pada imam atau pada dalil yang dijadikan argumen oleh imam, tetapi karena ada persetujuan pada metodologi yang digunakan oleh imam dalam berijtihad. Pertanyaan yang muncul adalah jika mereka memiliki kapasitas yang seta-ra dengan pendiri mazhab, mengapa mereka masih mengikuti mazhab imam dan ti-dak membentuk satu mazhab sendiri? (Wael B. Hallaq, 2001: 8).

Terkait dengan hal tersebut, Ibnu Shalah mengutip pendapat Abu Ishaq alIsfirayini (414/1027) tentang beberapa murid imam Syafii seperti al-Muzni, Ibnu Suraij (w. 306) dan murid Abu Hanifah; Abu Yusuf (w. 182) yang mengikuti imamnya karena setuju dengan metode ijtihad imam sementara mereka sendiri 
Diterbitkan oleh Fakultas Hukum

Universitas Ahmad Dahlan

steril dari tak-lid. Mengomentari pendapat Isfirayini tersebut, menurut Ibnu Shalah benar bahwa mereka memiliki beberapa ilmu yang menjadi prasyarat ijtihad mutlaq, tetapi tidak bisa dipungkiri bahwa dalam beberapa hal mereka mengambil perkara yang sudah jadi yang diformulasikan oleh pendiri mazhab (Ibnu Shalah, 2002: 89). Ibnu Shalah juga menyatakan bahwa munculnya mujahid mustaqil tidak tertutup kemungkinan pada zaman setelah imam Syafii.

Kedua, mujtahid muqayyad atau disebut juga ashâbu'l wujûh wa at-thuruq yang memiliki kemampuan untuk mengkonfirmasikan kebenaran pendapat dalam mazhab, mendalami ilmu fikih dan usul fikih, menguasai pola analogi (qiyâs), akan tetapi tidak bisa melampaui kemampuan imam dan keluar dari dalil dan metode yang digunakan dalam mazhab Syafii. Mujtahid para rangking ini jelas sama sekali tidak terlepas dari taklid pada imam mazhab, sebab beberapa variabel ijtihad mutlak seper-ti penguasaan terhadap hadis atau Bahasa Arab tidak mereka miliki sempurna. Ibnu Shalah menyatakan bahwa tokoh-tokoh dalam mazhab Syafii masuk dalam kategori ini. Ketika berfatwa, mereka tidak hanya bisa menerima pendapat yang sudah jadi, tetapi mereka juga boleh melakukan teoritisasi hukum (takhrîj) dan berijtihad secara independen. Pada batasan tertentu, Ibnu Shalah menyebutkan bahwa kadang-kadang ulama pada level ini bisa disebut lebih kapabel dari imam pendiri mazhab dalam menguasai permasalahan fikih, karena ia memiliki penguasaan terhadap metodologi ijtihad yang lebih detail dan telah teruji selama ratusan tahun (Ibnu Shalah, 2002: 95).

Tingkatan ketiga dari mujtahid muntasib adalah mujtahid yang memiliki kemampuan menghafal pendapat-pendapat dalam mazhab disertai dalil-dalilnya, mam-pu melakukan konfirmasi, klasifikasi, mempertahankan, dan mencari pendapat ter-kuat, akan tetapi mereka tidak sampai pada tingkatan derajat ashâbu'l wujûh wa at-thuruq. Mereka tidak pakar dalam ilmu usul fikih dan tidak pandai dalam melakukan takhrîj serta istinbâth. Generasi muta akhirîn yaitu generasi yang hidup dari akhir abad ke empat sampai pada masa Ibnu Shalah masuk ke dalam kategori ini. Kontribusi mereka cukup besar yaitu mereka mampu mengelaborasi hukum secara detail dan mampu melakukan penalaran untuk mencari status hukum untuk kasus yang baru mereka temui sesuai dengan prinsip-prinsip yang berlaku dalam mazhab Syafii. Mufti jenis keempat dalam sub bagian mujtahid muntasib adalah golongan transmitter (pe-riwayat) pendapat mazhab. Tingkat intelegensi golongan ini hanya pada kemampuan memahami permasalahan dan mengerti jawabannya, tetapi mereka tidak mengerti dari mana dalilnya dan tidak mampu melakukan analogi. Sehingga hak berfatwa ha-nya diberikan kepada mereka sebatas menstransmisikan (menyampaikan) apa yang sudah secara formal menjadi pendapat resmi mazhab. Jika tidak ada dalam teks resmi mazhab, dan masih berada pada tahap sederhana, mereka diizinkan untuk melakukan penalaran sesuai dengan prinsip mazhab Syafii, seperti dalam kasus pembebasan budak, di mana sama antara budak laki-laki dan budak perempuan. Namun jika kasus yang dihadapi cukup rumit dan tidak ditemukan adanya kaidah dalam mazhab, mere-ka tidak boleh berfatwa (al-imsâk 'ani'l futyâ fîhî) (Ibnu Shalah, 2002: 100). 
Kategori mufti kelima dari mujtahid muntasib yang dibuat oleh Ibnu Shalah secara non-formal adalah orang yang baru membaca dan memahami satu atau lebih kitab fikih, akan tetapi tidak termasuk kepada empat kategori sebelumnya. Jika suatu saat seorang awam meminta fatwa kepadanya mengenai hukum suatu permasalahan, ia dibolehkan untuk berfatwa jika tidak ada orang lain di negeri itu selain dia. Pada kasus ini orang awam dianggap bertaklid dengan imam, bukan bertaklid dengan si mufti. Jika mufti muqallid ini tidak menemukan jawaban terhadap kasus dari buku yang ia baca, ia tidak diperkenankan untuk melakukan analogi terhadap kasus-kasus dalam mazhab. Ringkasnya, tipologi Ibnu Shalah ini meliputi enam tingkatan yang disusun secara vertikal dari tingkatan yang paling otoritatif sampai tingkatan te-rendah (lowest grade). Tipologisasi Ibnu Shalah meninggalkan pengaruh yang besar di dalam mazhab Syafii, terutama setelah Imam Nawawi (676/1277) dalam al-Majmû' melakukan elaborasi terhadapnya (Imam Nawawi, tt: 72).

Tiga abad setelah periode Ibnu Shalah dan Nawawi, seorang fakih dari dinasti Utsmaniyah di Turki, Ahmad bin Kamal Pashazadeh (w 940/1533) menyusun tipologi para juris (fukahâ') dalam mazhab Hanafi. Menurutnya ada tujuh tingkatan fukahâ' dalam mazhab Hanafi (Ibnu Abidin, 1992: 77). Pertama, mujtahid fi al-syar'i seperti empat imam pendiri mazhab. Mereka adalah orang yang membangun metodologi pe-ngambilan hukum dalam usul fikih pertama kali tanpa bertaklid pada siapa pun, baik pada tataran metodologis ataupun pada tataran kasus fikih partikular. Kedua, muj-tahid fi madzhab seperti tiga sahabat Abu Hanifah, yaitu Abu Yusuf, Ahmad bin Zafr, Muhammad as-Syaibani. Mereka mampu berijtihad untuk menemukan satu hukum dari teks berdasarkan kaidah yang dibangun oleh pendiri mazhab. Sekalipun dalam beberapa kasus fikih tiga tokoh ini berbeda pendapat dengan imam mazhab, namun mereka tetap mengikutinya dalam masalah qawâiid ushûl (metodologi). Ketiga, muj-tahid fi masâil seperti al-Khassaf (261/874), al-Karkhi (340/951), al-Tahawi (321/933), al-Hulwani (456/1063) alSarakhsi (483/1090), al-Bazdawi (482/1089), dan Qadhi Khan (592/1195). Mereka tidak bisa keluar dari batasan-batasan mazhab Hanafi, baik pada permasalahan furû́ ataupun ushûl, akan tetapi mereka mampu men-derivasi hukum sesuai dengan kaidah yang telah ditetapkan dalam mazhab.

Keempat, ashâbu al- takhrîj seperti ar-Razi (593/1196). Juris pada tingkatan ini tidak memiliki kapasitas untuk berijtihad, tetapi tingkat intelektual mereka mampu untuk memperinci (tafshîl) pendapat yang umum (mujmal) dalam mazhab, meme-cahkan ambiguitas (muhtamal) dalam pendapat mazhab dan melakukan analogi (muqâyasah) permasalahan dari kasus baru dengan kasus yang pernah ditulis dalam mazhab Hanafi. Kelima, ashâbu al- tarjîh seperti al-Quduri (428/1036), kemampuan mereka adalah memilih pendapat dalam mazhab, mana yang riwayatnya lebih valid, mana yang benar dan mana yang konsisten dengan metode qiyâs. Keenam, peringkat muqallid yang kemampuan mereka adalah membedakan antara yang paling kuat, kuat dan lemah, seperti al-Fasih (680/1281), al-Musili (683/1284) dan al-Mahbubi (747/1346). Pada buku-buku yang mereka susun, 
Diterbitkan oleh Fakultas Hukum

Universitas Ahmad Dahlan

mereka tidak mencantumkan riwa-yat yang lemah dan perkataan yang tidak diakui dalam mazhab Hanafi. Ketujuh, mu-qallid di tingkat terendah, yaitu mereka yang tidak mampu melakukan seperti yang dilakukan oleh enam tingkatan di atasnya, tidak bisa membedakan kanan-kiri dan ti-dak mengerti mana utara mana selatan (Ibnu Abidin, 1992: 77).

\section{Fungsi Taklid dalam Mentransformasikan Otoritas dalam Mazhab}

Setelah mendeskripsikan tipologisasi di atas, Wael mengajak pembaca bukunya menguji signifikansi dari strukturisasi otoritas pada masing-masing mazhab di atas. Wael memulai analisisnya dengan menunjukkan anomali pada tipologi Mazhab Malik. Berbeda dengan mazhab Syafii dan Mazhab Hanafi, tipologi yang dibuat oleh Ibnu Rusyd ini disusun dengan skema terbalik. Tipologisasi ini tidak dijumpai dalam Adâbu'l Muftî Ibnu Shalah sebagai representasi hirarki mazhab Syafii dan Majmu'atu al-Rasâ il Ibnu Abidin dari mazhab Hanafi. Ibnu Rusyd tidak menyusun rangking dari mujtahid par execellence lalu berurutan sampai mujtahid kelas bawah. Sebaliknya ia menyusunnya dengan meletakkan mujtahid dengan kapasitas dan tingkat intelegensi rendah di atas dan meletakkan mujtahid tertinggi di urutan terakhir. Mengapa ada anomali seperti ini? Jawabannya adalah karena tipologi Ibnu Rusyd ditulis lebih awal dari tipologi-tipologi lain. Maka tidak mengejutkan jika ia tidak mengelaborasi struk-tur otoritas karena karyanya adalah refleksi dari kondisi dan iklim fikih di masanya. Tipologisasi ini menunjukkan bahwa loyalitas dan fanatisme terhadap mazhab belum mengental seperti yang terjadi satu abad kemudian di era Ibnu Shalah dan tiga abad kemudian di era Ibnu Kamal. Jarak antara masa penyusunan tipologi Ibnu Rusyd dan masa kristalisasi mazhab terlalu berdekatan. Ia bahkan mengatakan bahwa "sifat dan atribut yang harus dimiliki oleh seorang mufti tidak berubah berbarengan dengan berubahnya zaman". Statemen seperti ini berimplikasi atau bermakna bahwa antara imam Malik dan para sahabatnya bisa sederajat dalam kapasitas fatwa dengan ulama yang hidup pada zaman sesudahnya. Ibnu Rusyd tidak melakukan limitisasi mujtahid sesuai dengan periode seperti yang dibuat oleh ulama dari mazhab lainnya. Maka, tipe-tipe yang ia elaborasi satu sama lainnya independen, tidak berhubungan dan ti-dak hirarkis.

Detailitas dalam penyusunan tipologi pada karya Ibnu Shalah dan Ibnu Kamal sangat dominan. Tingkat detailitas yang tinggi pada karya Ibnu Shalah terjadi karena dua hal. Pertama, ia menulis karyanya tersebut dua setengah abad setelah berdirinya mazhab Syafii, di mana perkembangan mazhab dalam sejarah sudah bisa diamati se-cara jelas. Kedua, kesadaran mengenai pentingnya struktur otoritas dan adanya evo-lusi hukum Islam telah muncul pada diri Ibnu Shalah dan Ibnu Kamal. Dengan demi-kian pola tipologisasi hirarkis dan piramidis seperti yang digunakan oleh Ibnu Shalah dan Ibnu Kamal adalah dalam rangka untuk mendeskripsikan, membenarkan dan me-rasionalisasikan segala jenis aktivitas fikih di masa lalu. Selain itu, dengan melakukan strukturisasi ulama berdasarkan kapasitas keilmuan masing-masing, kita juga meng-konstruk (membentuk) masa depan mazhab di 
kemudian hari yang berjalan sesuai dengan alur yang telah ditetapkan berdasarkan stuktur otoritas. (Wael B. Hallaq, 2001: 20)

Setelah memaparkan dan menganalisa tipologi mufti pada tiga madzhab di atas, kita bisa menyimpulkan urgensi dan relevansi tipologisasi itu. Pertama, tipologisasi itu berguna untuk mendeskripsikan beragam aktivitas fikih yang ada seperti yang ditulis oleh masing-masing tipolog dan mengemukakan posibilitas kemunculan-nya. Ibnu Rusyd misalnya mengklaim bahwa tiga jenis mufti yang ia paparkan akan terus eksis sampai kapanpun. Kedua, konsekuensi dari tipologisasi adalah ditemu-kannya uraian mengenai jenis aktivitas fikih dan tugas seorang mufti. Wael B. Hallaq menyimpulkan bahwa ada lima lapisan aktivitas fikih, yaitu ijtihad, takhrîj, tarjîh taqlîd dan tashnîf. Tidak ada dari lima fungsi ini yang berdiri secara independen. Lima fungsi ini mereprentasikan aktivitas fikih yang satu sama lainnya saling terkait dan saling memanfaatkan melampaui tugas internal masing-masing. Oleh karena itu, seorang muqallid bisa menjadi seorang mufti, seorang mujtahid muqayyad bisa men-jadi mushannif, seorang mukharrij bisa menjadi seorang mujtahid dan seterusnya (Wael B. Hallaq, 2001: 23). Seorang mujtahid (kecuali imam pendiri mazhab) bisa pu-la menjadi seorang muqallid dan tentunya seorang mufti.

Tentang taklid, kesimpulan khusus yang disuguhkan oleh Wael B. Hallaq ada-lah pertama, taklid dapat dipahami dari tipologi para ulama di atas sebagai komitmen untuk mempelajari doktrin mazhab, mengembangkan atau bahkan melakukan pem-belaan terhadapnya. Kedua, jika ijtihad selalu dilakukan secara mutlak (tanpa meng-indahkan kaidah yang telah dibangun sebelumnya) sama seperti yang dilakukan pen-diri mazhab, maka sampai sekarang tidak akan berdiri satu mazhab pun, sebab yang ada hanyalah mujtahid-mujtahid independen. Ketiga, taklidlah yang menjamin keber-langsungan (survival) empat mazhab fikih yang sekarang kita kenal. Maka taklid ada-lah agen yang diperlukan untuk memediasi otoritas dari satu generasi ke generasi se-lanjutnya (Wael B. Hallaq, 2001: 23). Wael B. Hallaq menyimpulkan bahwa perubahan (change, tajdîd) dalam hukum Islam dilakukan melalui hubungan yang saling mem-pengaruhi (interplay) antara ijtihad dan taklid. Oleh karenanya, tuduhan beberapa orientalis dan pembacaan negatif umat Islam terhadap taklid yang selama ini telah la-ma dipertahankan justru tidak beralasan.

\section{Catatan Kritis untuk Wael B. Hallaq}

Sebagaimana dikatakan di muka bahwa temuan Wael B. Hallaq mengenai tak-lid berbeda dengan tesis kebanyakan orientalis lainnya. Hal itu tidaklah aneh karena Wael B. Hallaq di sini berdiri sebagai seorang scholar yang relatif tidak memiliki ke-pentingan dengan hasil kajiannya sehingga ia dengan bebas bisa memunculkan tesa apapun. Pada sisi inilah muncul relevansi untuk memberikan catatan terhadap te-muan Wael B. Hallaq. Berkenaan dengan taklid, penulis berpandangan bahwa per-spektif yang digunakan oleh Wael tidaklah kompatibel jika diukur dengan kredo kaum modernis atau pembaharu. Jika taklid hanya 
Diterbitkan oleh Fakultas Hukum

Universitas Ahmad Dahlan

didekati melalui sejarah (historical approach) an sich, maka taklid akan tampak sebagai elemen positif yang membentuk otoritas dalam fikih Islam. Padahal, menurut hemat penulis apa yang selama ini di-musykilkan para ulama tentang taklid tidaklah sesederhana itu. Para ulama ber-keyakinan bahwa taklid bukan saja telah memediasi otoritas dalam satu mazhab dari fukahâ' satu generasi ke generasi sesudahnya seperti disimpulkan oleh Wael, tetapi juga telah menjadi penanggungjawab utama matinya kreatifitas pemikiran hukum Is-lam. Maka selain pendekatan sejarah, diperlukan juga pendekatan kritis (critical app-roach) untuk membaca taklid supaya ada pemahaman yang lebih integral.

Catatan sejarah mengatakan bahwa stagnasi pemikiran hukum Islam terjadi karena para ulama menyerukan taklid. Selain mazhab Hanbali, tiga mazhab lainnya semuanya pernah terjebak pada pandangan yang mengatakan bahwa suatu zaman boleh tidak ada mujtahidnya (Yusuf Qardlawi, 1999: 106, Abu Zahrah, 1996: 332333). Para ulama pernah menyerukan bahwa taklid adalah sesuatu yang wajib, sementara ijtihad harus dijauhi (amran munkaran). Ibnu Abi Dam, seorang tokoh dalam mazhab Syafii, mengatakan pada masanya tidak boleh lagi ada mujtahid mutlak, bah-kan mujtahid dalam mazhab imam (Yusuf Qaradlawi, 1999: 106). AlKarkhi, seorang juris dari mazhab Hanafi, lebih ekstrim lagi, ia menyebutkan bahwa setiap ayat al-Quran dan Hadis yang tidak sesuai dengan pendapat mazhab Hanafi harus ditak-wilkan (Sayyid Sabiq, 2008 : 9). Catatan sejarah juga menunjukkan bahwa taklid telah membekukan loyalitas juris-juris pada mazhabnya sendirisendiri, bukan pada teks al-Quran dan Sunah. Jika kondisi nya seperti itu, maka justru adanya taklid dalam se-jarah fikih Islam adalah hal yang kontraproduktif dengan adanya kewajiban berijtihad dari umat Islam pada setiap masa.

Memang betul bahwa taklid lahir secara alami (by nature) karena dua faktor: (1) adanya perbedaan generasi khalaf (saat ini) dalam tingkatan pemahaman fikih dibandingkan generasi salaf (masa lalu/pendahulu) dan (2) disebabkan oleh telah terbakukannya metodologi interaksi dengan teks pada periode sebelumnya. Namun yang menjadi masalah adalah di kemudian hari taklidlah yang memasung kreatifitas dan progresifitas berfikir, melahirkan fanatisme buta dan sikap inferior sehingga berujung pada sakralisasi pendapat para imam mazhab.

Kapasitas setiap individu dalam berijtihad memang tidaklah sama, tetapi adanya sistem hirarki dalam berijtihad yang pada ujungnya melarang seorang juris bertindak leluasa dalam menghasilkan sebuah hukum tidaklah perlu terjadi. Ibnu Taimiyah misalnya, seorang ulama yang getol menyerukan ijtihad, menulis bahwa taklid bukanlah sesuatu yang haram. Menurutnya, taklid dibolehkan karena beberapa alasan: (1) dalil yang ada sudah mapan; (2) waktu yang dimiliki seorang juris sempit (Ibnu Taimiyah, tt: XX/114). Namun, sekalipun legal, taklid tidak boleh dibiarkan menghinggap pada setiap generasi dan pada setiap orang. Karena jika begitu berarti fikih tidak lebih dari sekedar ilmu tentang periwayatan (transmisi) pendapat juris an-tara satu generasi ke generasi sesudahnya saja.

Para juris generasi awal telah mengingatkan bahwa taklid tidak diperlukan dalam mengambil pendapat mereka. Dalam hal ini, Ibnu Taimiyah (XX: 117) menulis 
dengan judul kecil dalam Majmû'atu Fatâwâ-nya الأيمة الأربعة نهوا عن تقليدهم (larangan para imam mazhab untuk taklid kepada mereka). Mereka tidak membolehkan penda-pat mereka diikuti tanpa diketahui landasan berfikir (dalilnya). Ini membuktikan apa yang dibela oleh Wael bahwa taklid diperlukan untuk melahirkan loyalitas pada mazhab tidaklah relevan. Karena para imam pendiri mazhab sendiri tidak meng-inginkan kekakuan seperti itu terjadi. Khusus untuk masa sekarang, antara berbagai disiplin ilmu telah ada keterbukaan, tidak lagi kaku (esklusif) dan masing-masing sudah bisa saling menyapa. Maka rigiditas yang terjadi di ranah fikih yang mengkaji-batkan seorang juris akan melakukan sikap defensif yang berlebihan terhadap maz-habnya memang sudah tidak penting lagi untuk diperjuangkan. Pembelaan yang di-lakukan Wael B. Hallaq terhadap taklid akan bertentangan dengan kesadaran sejarah para juris periode ini bahwa taklid tidaklah dibutuhkan lagi.

\section{Kesimpulan dan Saran}

Kajian Wael B. Hallaq tentang ragam dan jenis aktivitas dalam hukum Islam cukup kontributif terhadap kajian hukum Islam. Namun, kesimpulannya tentang tak-lid bahwa ia adalah elemen positif yang berfungsi untuk membangun loyalitas dan ko-mitmen untuk mempelajari mazhab, melahirkan sikap defensif terhadap mazhab-mazhab lainnya tidaklah relevan jika dilihat dari sudut pandang kaum modernis. Se-bab taklid selain telah membangun otoritas mazhab, juga bertanggungjawab atas terpasungnya kreatifitas dan progesifitas dalam hukum Islam.

Tulisan ini diakhiri dengan saran agar pemikiran Wael B Hallaq dalam bidang teori hukum Islam dibedah dan dikaji dengan semangat apresiatif dan kritis sekaligus. Bagi penulis, Hallaq dengan karya-karyanya yang sangat besar jumlahnya sungguh adalah anugerah Tuhan bagi kesarjanaan Islam di bidang hukum.

\section{DAFTAR PUSTAKA}

\section{BUKU DAN JURNAL}

Abdul Raziq, Mustafa. 2007. al-Tamhîd li Târîkhi'l Falsafati'l Islâmiyah. Kairo. Maktabah al-Tsaqafah al-Islamiyah.

Abid al-Jabiri, Muhammad. 1990. Takwînu'l 'Aqli'l 'Araby. Beirut. Markaz Dirasah alWahdah al-Arabiyyah.

Abu Zahrah, Muhammad. 1996. Târîkhu'l Madzâhibi'l Islâmiyah fi Siyâsah wa'l 'Aqâ ìd wa Târîkhu'l Madzâhibi'l Fiqhiyyah. Kairo. Darul Fikril Arabiy.

Al-Wansharisi, Ahmad bin Yahya. 1981. al-Mi'yâru'l Mughrib wa'l Jâmi'i'l Mughrib. Maroko. Wizarah al-Awqaf wa al-Syuun al-Islamiyah li al-Mamlakah alMaghribiyah. 
Diterbitkan oleh Fakultas Hukum

Universitas Ahmad Dahlan

Gib, Hamilton. 1979. Studies on the Civilization of Islam (terjemahan dalam bahasa Arab oleh Ihsan Abbas, dkk. Dirâsah fí Hadlârati'l Islâm). Beirut. Dar al-Ilmi li al-Malayin.

Hallaq, Wael B. 2001. A History of Islamic Legal Theories: An Introduction to Sunni Ushul Fiqh (terjemahan dalam bahasa Indonesia oleh E. Kusnadiningrat dan Abdul Haris Sejarah Teori Hukum Islam Pengantar untuk Studi Usul Fiqh Mazhab Sunni). Jakarta. Raja Grafindo Persada. 2001. Authority, Continuity and Change in Islamic Law. Cambridge: Cambridge University Press.

Ibnu Abidin, Muhammad Amin. 1992. Raddu'l Mukhtâr 'alâ Duri'l Mukhtâr. Beirut. Dar a-Fikr.

Ibnu Shalah. 2002. Fatâwâ Ibni Shalâh. Madinah. Maktabah al-Ulum wa al-Hikam. Taqiyuddin, Ibnu Taimiyah. tt. Majmû'atu'l Fatâwâ. Kairo. Maktabah Tawfiqiyyah.

Muslehuddin, Muhammad. 1991. Philosophy of Islamic Law and The Orientalist A Comparative Study of Islamic Legal System (terjemahan dalam bahasa Indonesia oleh Yudian Wahyudi Filsafat Hukum Islam dan Pemikiran Orientalis). Yogyakarta. Tiara Wacana.

Nawawi, Abu Zakariya. tt. Al-Majmû'. Jeddah. Maktabatul Irsyad.

Qardlawi, Yusuf. 1999. al-Ijtihâd fí Syarî'ati'l Islâmiyah ma'a Nazharât Tahlîliyah fi Ijtihâdi'l-Mu'ashir. Kuwait. Darul Qalam.

Sabiq, Sayyid. 2008. Fiqhu al-Sunnah. Kairo. Al-Fathu lil I'lam Arabiy. 